\title{
Establishment of the multidisciplinary Committee for Control and Prevention of Infections as key factor for the rationalization of antibiotic utilization in Clinical Hospital Acibadem Sistina-Skopje
}

\author{
Dragana Buhov $^{1 *}$, Zorica Naumovska ${ }^{2}$, Ljubica Suturkova ${ }^{2}$ \\ ${ }^{1}$ Clinical Hospital Acibadem Sistina-Skopje, Skupi 5A, 1000 Skopje, R. N. Macedonia \\ ${ }^{2}$ Institute of Pharmaceutical Chemistry, Faculty of Pharmacy, \\ Ss. Cyril and Methodius University, Mother Theresa 47, 1000 Skopje, R. N. Macedonia
}

Received: July 2019; Accepted: August 2019

\begin{abstract}
Antibiotics are indicated in the prevention and treatment of bacterial infections. Antibiotic resistance is a global healthcare problem, strongly connected to hospital-acquired infections. As drug resistance is world-wild problem new educational programs and prescribing and utilization strategies should be developed.

Evaluation of the implementation of the measures by Committee for control and prevention of infections at Clinical Hospital Acibadem Sistina-Skopje and assessment of its function in the monitoring of the level of infections and rationalization in antibiotics prescription in hospitalized patients.

Isolates taken from patients in the Clinical Hospital Acibadem Sistina-Skopje were used in this study. Monthly and annual analysis was performed by pharmacist for a controlled group of antibiotics prescribed based on obtained antibiogram results confirmed by a microbiologist.The Committee for Control and Prevention of Infections also monitors the consumption of antibiotics on a monthly and annual basis calculated through the list of published antibiotics in defined daily doses (DDD-Defined daily doses) per 1000 hospital days.

Obtained results present that consumption of controlled antibiotics is stable in the evaluated period with a tendency of declination. They are used in indicated patients with the exception of Imipenem/Cilastatin. The evaluation of previously applied to proscribe routine for this combined antibiotic suggested that the patients were sub-dosed. The applied measure resulted in rational and appropriate dosing of the patients and coherent increased consumption of Imipenem/Cilastatin. The second measure applied was associated with the rationalization of surgical profilaxis and substitution of ceftriaxone with cefazolin. The costs in 2016 were 12421100 MKD (201969 Eur), compared to the expenditures in 2017 of 11891000 MKD. (193 349 Eur).

Implementation of appropriate measures by establishment of the Committee led to the reduction of irrational antibiotics utilization and decrease of the antibiotics associated expenditure in the Clinical Hospital Acibadem Sistina.
\end{abstract}

Keywords: antibiotics, antibiotic resistance, rational antibiotic utilization, expenditures

\section{Introduction}

Antibiotics are indicated in the prevention and treatment of bacterial infections. Microorganisms that develop antimicrobial resistance are sometimes referred to as "superbugs". As a result, the medicines become ineffective and infections persist in the body, increasing the risk of spread to others (WHO, 2018). Irrational antibiotics utilization is the main reason for antibiotics

\footnotetext{
*dragana.buhov@acibademsistina.mk
} 
resistance occurrence. Antibiotic resistance is a global healthcare problem, strongly connected to hospitalacquired infections. Additionally, it is nowadays a vast problem, a hazard for healthcare systems worldwide, rising at an alarming rate. Antibiotic overconsumption has a prominent position among its causes followed by inappropriate antibiotic prescribing and by providing antibiotics without prescription. Treatment of common infections will be a challenge as few new antibiotics are being developed, limiting the prescribing choices. Multiresistant microorganisms are the cause of many hospitalacquired infections, a leading cause of morbidity and mortality. (Milori and Migliori, 2017)

As drug resistance is world-wild problem new educational programs and prescribing and utilization strategies should be developed. Even if new antibiotics are developed without behavior change like a regular vaccination, hand washing, safer sex attitude, and good food hygiene, antibiotic resistance will remain a major threat. Antibiotic resistance has direct consequence which is expressed to higher medical costs, prolonged hospital stays, and increased mortality (National Institute of Allergy and Infectious Diseases.Antimicrobial Drug Resistance, 2016).

In order to obtain rationalization of antibiotics consumption and prevent hospital-acquired infections, a multidisciplinary Committee for control and prevention of intra-hospital infections at the Clinical Hospital Acibadem Sistina was established. The founding of the Committee for control and prevention of infections is recognized by Law. This Committee is founded in order to improve safety, by implementation of the following measures: monitoring of infections, implementation of valid guidelines for patient precautions and isolation measures, introduction of procedures and guidelines in the field of prevention and control of infections, conduction of randomized controls on the non-living environment and readiness to deal with a possible epidemic or an existing epidemic.

The aim of the study was to evaluate the implementation of the measures by the Committee for control and prevention of infections at Clinical Hospital Acibadem Sistina-Skopje and to assess its function in the monitoring of the level of infections and rationalization in antibiotics prescription in hospitalized patients.

\section{Materials and methods}

In the Clinical Hospital Acibadem Sistina, the double model of proving and reporting infections is accepted as follows: Clinical proving the presence of infection and Laboratory Evidence of the Infection (LaboratoryIdentified (LabID) Event Reporting). Clinical evidence is based on pre-established criteria for the diagnosis of specific infection by the Center for Disease Control and Prevention and the National Healthcare Safety Network (NHSN). Laboratory proof of the samples taken is performed in the Laboratory for Microbiology and Parasitology at the Clinical Hospital Acibadem SistinaSkopje. Monthly and annual analysis are performed for a controlled group of antibiotics prescribed based on obtained antibiogram results confirmed by a microbiologist. The pharmacist, member of the Committee for control and prevention of infections at Clinical Hospital Acibadem Sistina-Skopje, is preparing monthly and annual reports for the consumption of all antibiotics, including controlled antibiotics. These data are presented on the meetings of the Committee for control and prevention of infections, and adequate measures are undertaken. Health-associated infections (HAIs), although preventable, greatly endanger patient safety. Their monitoring and processing of statistics serve as a reference to the rise or fall of operations in terms of increasing patient and staff safety.Types of infections that were assessed in the study are Hospital-associated infections (HAIs) divided into Urinary tract infections associated with a urinary catheter (CAUTI) and Septicemia or "Bloodstream Infection" (BSI) with the statistically most important subgroup of septicemia associated with the use of a central venous catheter (CLABSI - Central LineAssociated BloodStream infection); Pneumonia (PNEU) with a significantly important subgroup - VentilatorAssociated Pneumonia associated with mechanical ventilation (VAP) and SSI (Surgical Site Infection).

The Committee for Control and Prevention of Infections also monitors the consumption of antibiotics on a monthly and annual basis calculated through the list of published antibiotics in defined daily doses (DDDDefined daily doses) per 1000 hospital days. The definition of DDD is the assumed average daily maintenance dose for a drug used for its main indication with adults. This formulation is used to standardize the comparison between different drugs and/or between different healthcare institutions. DDD should not be identified with the therapeutic dose and/or the actual dose that is prescribed by doctors. The calculation is by dividing the total monthly amount of the antibiotic with DDD and then dividing it with the total number of hospital days of patients in the current month. The achieved result is multiplied by a thousand to obtain a statistically applicable value, using the formula below:

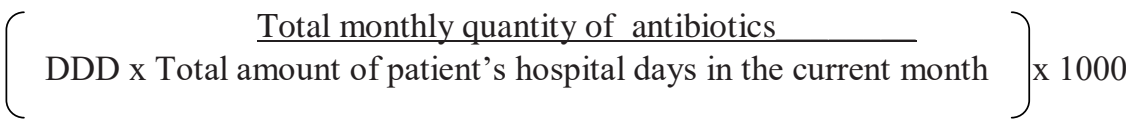

Maced. pharm. bull., 65 (1) $67-81$ (2019) 
The results are analyzed by members of the Committee for the Control and Prevention of Infections and accordingly, some measures are taken (eg, education of antibiotic prescribing physicians; use of firstgeneration cephalosporins for antimicrobial). The goal is to treat patients with the right antibiotic to avoid the emergence of antimicrobial resistance.

\section{Results}

The results presented in this survey are approved by the Committee for Control and Prevention of Infections and Committee for Ethics at Clinical Hospital Acibadem Sistina-Skopje.

The frequency of most commonly isolated bacteria obtained in the study is presented in Table 1.

Table 2 presents the groups of evaluated antibiotics utilization and indications for their prescription (U.S. National Library of Medicine, 2018).

Table 1, Figure 1 and Figure 2 illustrate the previously defined controlled antibiotics utilization for certain indications in time frame od 4 years, period 20152018 .

Table 1. Frequency of most commonly isolated bacteria

\begin{tabular}{ll}
\hline Bacterial type & $\%$ \\
\hline Enterococcus spp. & $20.51 \%$ \\
Staphylococcus aureus & $18.64 \%$ \\
Escherichia coli & $14.23 \%$ \\
Acinetobacter baumannii & $9.25 \%$ \\
Pseudomonas aeruginosa & $5.70 \%$ \\
Candida albicans & $5.27 \%$ \\
Acinetobacter baumannii MDRO & $4.41 \%$ \\
Klebsiella pneumoniae ESBL+ & $4.17 \%$ \\
Klebsiella pneumonia & $3.74 \%$ \\
Methicillin-resistant Staphylococcus aureus (MRSA) & $3.02 \%$ \\
Streptococcus pneumonia & $2.11 \%$ \\
Streptococcus agalactiae & $1.72 \%$ \\
Proteus mirabilis & $1.29 \%$ \\
Streptococcus alpha-haemolyticus & $1.29 \%$ \\
Streptococcus beta-haemolyticus gr. C & $0.91 \%$ \\
Non-albicans Candida spp. & $0.81 \%$ \\
Clostridium difficile & $0.77 \%$ \\
Escherichia coli ESBL+ & $0.77 \%$ \\
Enterobacter aerogenes & $0.34 \%$ \\
Morganella morganii & $0.24 \%$ \\
Rhodotorula rubra & $0.14 \%$ \\
Stenotrophomonas maltophilia & $0.14 \%$ \\
Serratia marcescens & $0.10 \%$ \\
Bacteroides fragilis & $0.05 \%$ \\
Bacteroides spp. & $0.05 \%$ \\
Citrobacter spp. & $0.05 \%$ \\
Enterococcus faecium & $0.05 \%$ \\
Peptostreptococcus & $0.05 \%$ \\
Proteus mirabilis ESBL+ & $0.05 \%$ \\
Providencia rettgeri & $0.05 \%$ \\
Providencia stuartii & $0.05 \%$ \\
\hline & $0.05 \%$ \\
\hline
\end{tabular}

Макед. фарм. билт., 65 (2) 67 - 81 (2019) 
Table 2. Group of antibiotics and indication for their use

\begin{tabular}{|c|c|}
\hline Group of antibiotics & Indication \\
\hline \multirow{6}{*}{ Penicillins } & Hospital-acquired and ventilator-associated pneumonia \\
\hline & Complicated urinary tract infections \\
\hline & Broncho-pulmonary infections in cystic fibrosis \\
\hline & Complicated intra-abdominal infections \\
\hline & Complicated skin and soft tissue infections \\
\hline & Acute bacterial meningitis \\
\hline \multirow{5}{*}{ Carbapenems } & Complicated intra-abdominal infections \\
\hline & Pneumonia including hospital and ventilator-associated pneumonia \\
\hline & Intra- and post-partum infections \\
\hline & Complicated urinary tract infections \\
\hline & Complicated skin, and soft-tissue infections \\
\hline \multirow{7}{*}{ Glycopeptides } & Complicated skin and soft tissue infections \\
\hline & Bone and joint infections \\
\hline & Community-acquired pneumonia \\
\hline & Hospital-acquired pneumonia \\
\hline & Ventilator-associated pneumonia \\
\hline & Infective endocarditis \\
\hline & for the perioperative antibacterial prophylaxis \\
\hline \multirow{3}{*}{ Oxazolidinone } & Complicated skin and soft tissue infections \\
\hline & Community-acquired pneumonia \\
\hline & Nosocomial pneumonia \\
\hline
\end{tabular}

Obtained results present that the consumption of controlled antibiotics is stable in the evaluated period with a tendency of declination. They were proscribed and utilized in an indicated patient with the exception of Imipenem/Cilastatin. The evaluation of previously applied proscribing routine for this combined antibiotic suggested that it was prescribed $500 \mathrm{mg} / 500 \mathrm{mg}$ every 8 hours, i.e. implicating that the patients were sub-dosed. They did not receive the required dose of $1000 \mathrm{mg} / 1000 \mathrm{mg}$ every 8 hours or $500 \mathrm{mg} / 500 \mathrm{mg}$ every 6 hours. Following the recommendation of the pharmacist and microbiologist as Members of the Committee for the Control and Prevention of Infections, all doctors were informed of changes that need to be applied in administration regime in order to avoid improper use of this antibiotic, which is usually associated with antibiotic resistance. The suggestion was accepted and implemented by doctors and the second dose applied to the patient was the dose prescribed by a pharmacist. This applied measure resulted in rational and appropriate dosing of the patients and coherent increased consumption of Imipenem/Cilastatin.

The Consumption of antibiotics presented in Figure 2 shows that in 2016 year there was the highest portrayal of these antibiotics. Since 2017, their consumption has begun to decrease.

The Committee for the Control and Prevention of Infections at the Clinical Hospital Acibadem Sistina in cooperation with the Committee for Medication Management took the initiative to change the antibiotic used for surgical prophylaxis. Namely, the increased occurrence of a multidrug-resistant organism is the result of the abuse of antibiotics by the population. The same statistically cannot be associated with the abuse of antibiotics in a hospital environment, because in most patients, the administration of antibiotics is according to an antibiogram, or if an antibiotic is given for surgical 

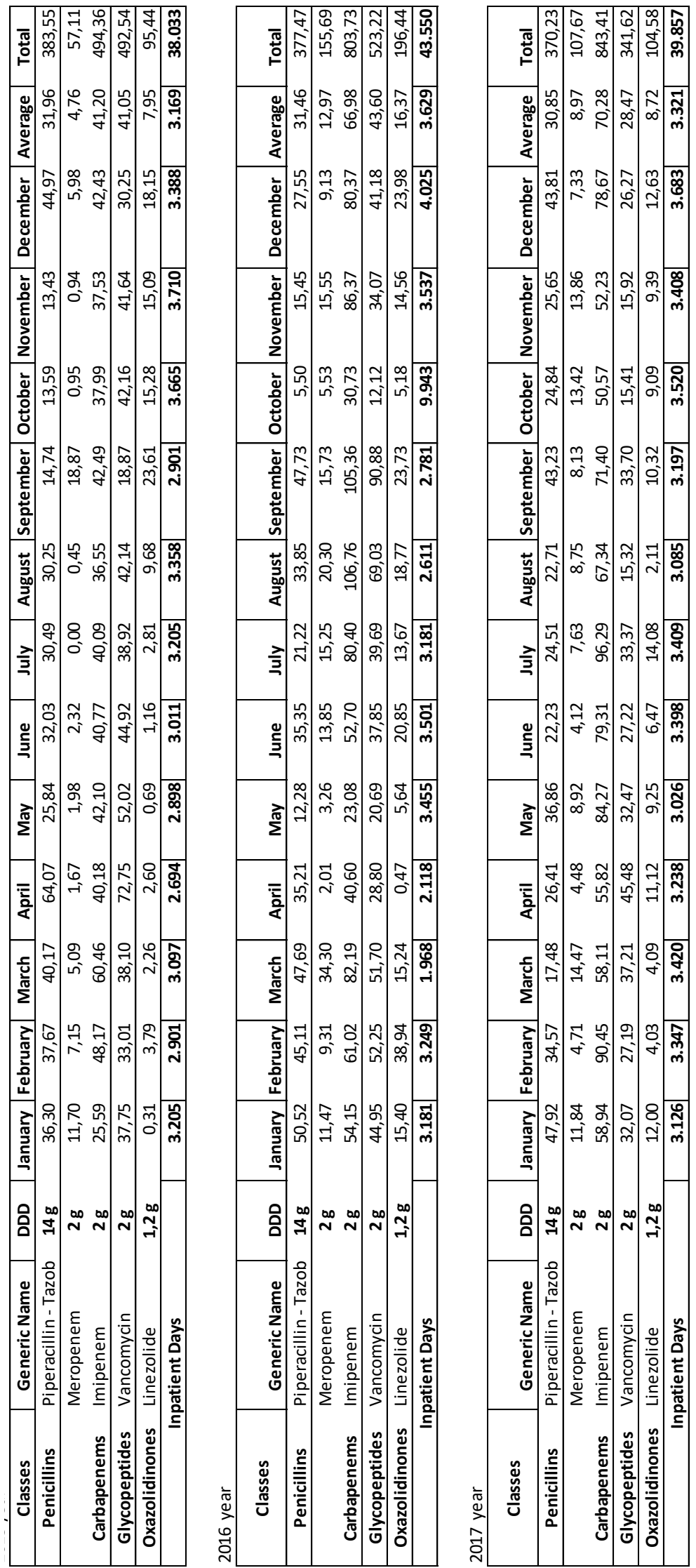

Fig. 1. Monthly utilization of group controlled antibiotics for the period 2015-2018 presented as DDD (Defined Daily Dose) per 1000 hospital days.

Макед. фарм. билт., 65 (2) $67-81$ (2019) 


\section{Consumption of controlled antibiotics}

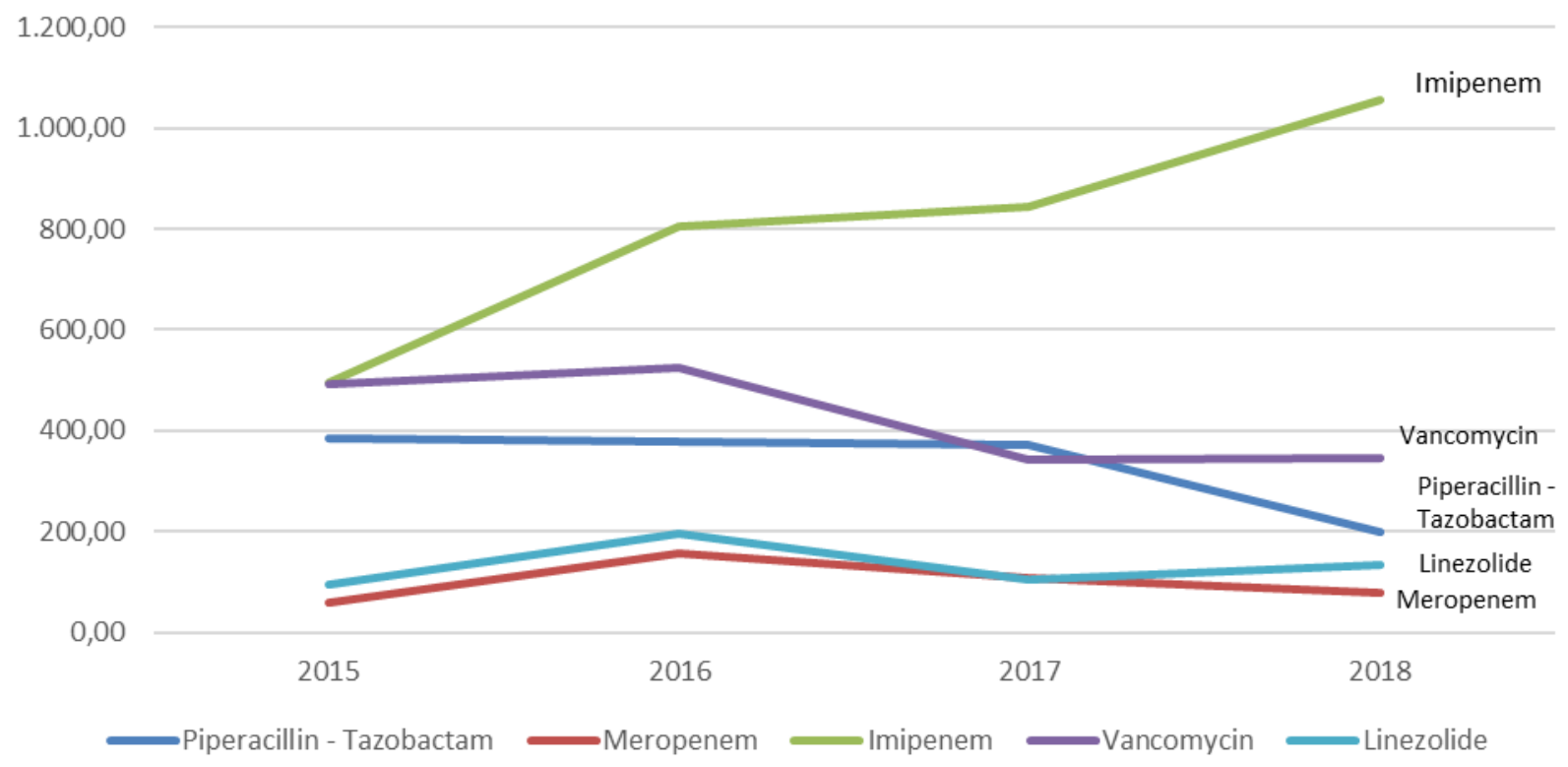

Fig. 2. Graphic presentation of controlled antibiotics consumption (antibiotics quantity/DDD/inpatient days) x 1000 .

prophylaxis, an appropriate antibiotic is used. Cephalosporins were the most frequently prescribed antibiotics.

In Clinical Hospital Acibadem Sistina an antibiotic for surgical prophylaxis as the first drug of choice was an antibiotic from the third generation cephalosporins group- ceftriaxone. In 2017 as an antibiotic for surgical prophylaxis is used a first-generation cephalosporin antibiotic-cefazolin.

Consumption of cefazolin $1 \mathrm{~g}$ was 0 vials in 2016 and 7665 vials in 2017 and of ceftriaxone 11301 vials in 2016, compared to 10810 vials in 2017 (Fig. 3).

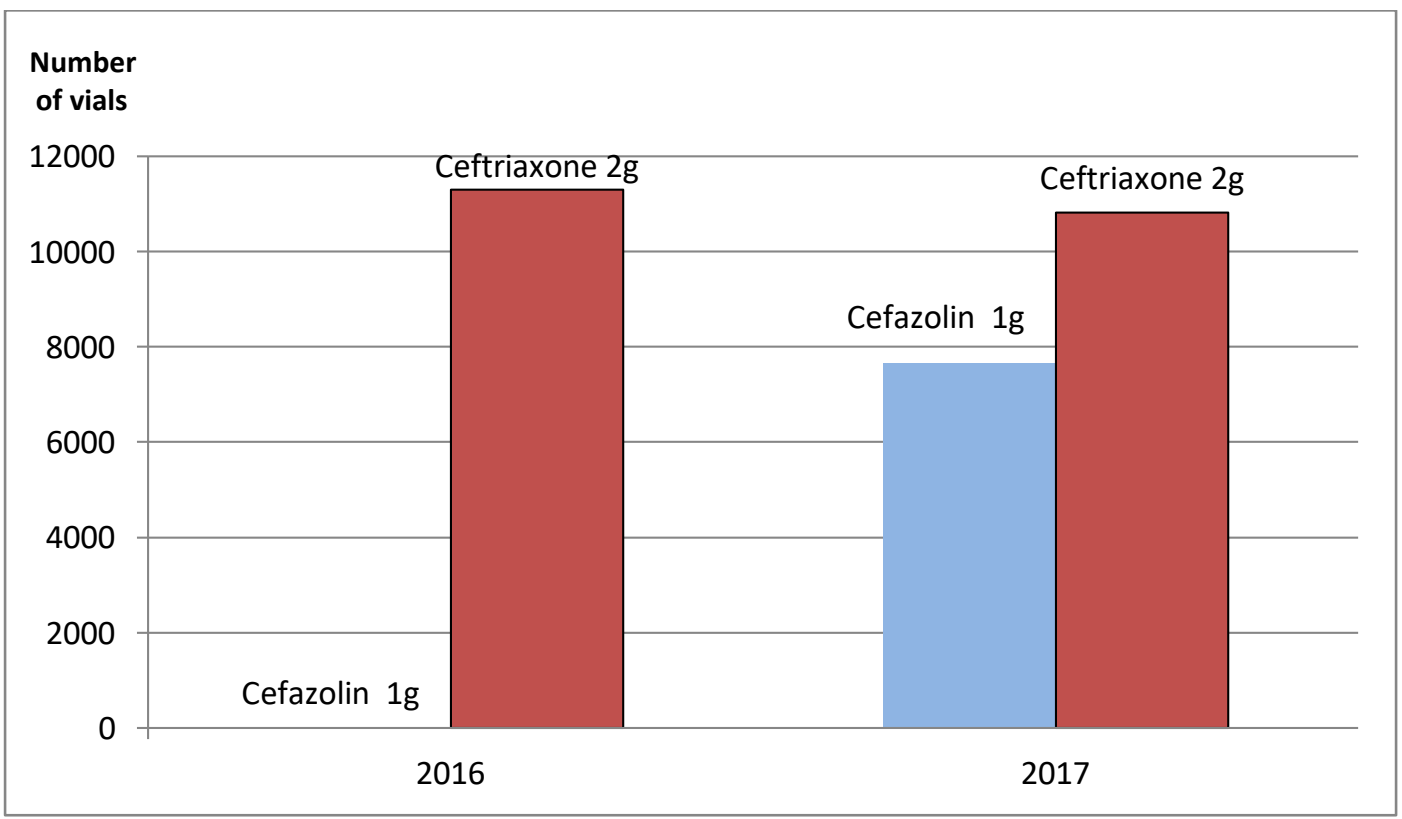

Fig. 3. Graphic consumption of ceftriaxone and cefazolin in 2016 and 2017. 


\section{Discussion}

Unnecessary or inappropriate use of antibiotics can have negative consequences for patient outcome and the development of antimicrobial resistance. To curb the development of antibiotic resistance, better use of current agents and a decrease of inappropriate antibiotic use are necessary. Antibiotic stewardship programs can improve antibiotic use and reduce healthcare costs without negatively influencing the quality of care provided (Rizi et al., 2018). One of the key elements of an effective stewardship program is its ability to monitor the quality of hospital antibiotic use, with the aim of setting priorities and focus improvement.The results shown in Table 1 correspond to the following literature data on the most commonly isolated bacteria. Nevertheless, the patient population sampled had very high levels of resistance to third-generation cephalosporins (cefotaxime/ceftriaxone and ceftazidime), aminoglycosides (gentamicin/ tobramycin) and fluoroquinolones (ciprofloxacin/ levofloxacin/ofloxacin) in E. coli and $K$. pneumoniae. In $K$. pneumoniae, four isolates $(17 \%)$ were carbapenemresistant. Importantly, the observed resistance percentage for ertapenem (0\%) was lower than for imipenem/meropenem in $K$. pneumoniae. The proportion of MRSA was concerning. Too few antibiotic susceptibility testing results for $P$. aeruginosa and $S$. pneumoniae were available to allow interpretation. The high levels of resistance in Acinetobacter spp. and E. faecium is concerning and may reflect the dissemination of resistant clones in the health care settings. The species distribution suggests that the data represent a mix of hospital-associated and community-acquired infections. However, the overrepresentation of more severely ill and pretreated patients receiving tertiary care and an overall small number of isolates constrain the representativeness of the results. The antibiotic susceptibility testing results seem to be reliable and comparable. The data indicate the resistance patterns present in clinical settings in the country, but the percentages of resistance should be interpreted with care. Increasing the utilization of blood culture diagnostics, especially in regional hospitals, will lead to a more valid assessment of antimicrobial medicines resistance, or AMR in the country (WHO, 2012). AMR is defined as the resistance of bacterial, viral, parasitic and fungal microorganisms to antimicrobial medicines that were previously effective for the treatment of infections. If no action is taken to contain AMR, the economic cost in terms of lost global production between now and 2050 would be US\$ 100 trillion. Low- and middle-income countries would be more negatively impacted and a widening of the inequity gap within countries is expected. Antibiotic resistance increases the costs of treatment because of longer hospital stays, more expensive antibiotic drug use and treatment, as well as indirect costs to families and society. (Van den Bosch et al., 2016; WHO, 2017; 2018)
Observing the past decades, it can be noticed that with the slow rate of development and introduction of new antimicrobial drugs, resistant clinical isolates were observed copiously. The direct effect of the above mentioned is the production of ineffective and inappropriate antibiotics, that are used to treat and control bacterial infections. What has brought confusion to pharmaceutical scientists is the fantastic and potent ability of bacteria to acquire antibiotic resistance, when analyzed from a development point of view. Nevertheless, after the development and introduction of antibiotics into the clinic, this resistive force has significantly increased, culminating in a remarkable speed in the evolution and spread of resistance indications in bacteria. This is especially due to the fact that once bacteria acquire resistance to antimicrobial drugs, the resistance is lost at a relatively slow pace. In comparison, total antibiotic consumption in Serbia for systemic use has been reduced by $32.8 \%$, from 36.5 defined daily doses per 1000 inhabitants in 2015 to 24.53 in 2017 . The public was warned that excessive use of antibiotics by certain bacteria became resistant to them and that infections caused by such bacteria could lead to a complicated treatment or even fatal outcomes. (United Nations, 2018)

\section{Conclusion}

Implementation of appropriate measures by the establishment of the Committee led to the reduction of irrational antibiotics utilization and decrease of the antibiotics associated expenditure in the Clinical Hospital Acibadem Sistina. Presented results revealed that firstgeneration cephalosporin cefazolin was the substitution of a previously utilized third-generation cephalosporin, ceftriaxone, as an antibiotic for surgical prophylaxis. This measure resulted in a serious decrease in ceftriaxone consumption for prophylaxis and a reduction in hospital expenditures. The costs in 2016 were 12421100 MKD (201969 Eur), compared to the expenditures in 2017 of 11891000 MKD. (193 349 Eur).

Presented results implicate that in the Clinical Hospital Acibadem Sistina the utilization of antibiotics is vigorously monitored on a monthly and annual level and it is within controlled limits. For each deviation (increase) of the consumption of an antibiotic, the Committee for the Control and Prevention of Infections makes an analysis of the justification of this deviation, evaluating the factors led to enlarged expenditures.

\section{References}

Milori, A., Migliori, E., 2017. Antibiotic Resistance and Infection Control: Physicians Aspects and Beliefs. J. Antimicrob. Agents 3(2), 1-3. Available at: https://doi.org/10.4172/2472-1212.100013.

National Institute of Allergy and Infectious 
Diseases.Antimicrobial Drug Resistance, 2016. 5-13. Available at:

https://www.niaid.nih.gov/research/antimicrobialresistance.

Rizi, K.S., Ghazvini, K., Noghondar, M.K., 2018. Adaptive Antibiotic Resistance: Overview and Perspectives Department of Microbiology and Virology, J. Infect. Dis. Ther. 6(3), 1-4. Available at: https://doi.org/10.4172/23320877.1000363 .

United Nations, 2018. Consumption of antibiotics in Serbia reduces by $38,2 \%$. Available at:

https://serbia.un.org/11820-consumption-antibioticsserbia-reduced-382.

U.S. National Library of Medicine, 2018. About Bacteria and Antibiotics , 1-3. Available at: https://medlineplus.gov/antibiotics.html\#summar.

Van den Bosch, C.M., Hulscher, M.E., Natsch, S., Wille, J., Prins, J.M., Geerlings, S.E., 2016. Applicability of generic quality indicators for appropriate antibiotic use in daily hospital practice: a cross-sectional point-prevalence multicenter study. Clin. Microbiol. Infect. 22(10), Available at: https://doi.org/10.1016/j.cmi.2016.07.011.
World Health Organization, 2012. Central Asian and Eastern European Surveillance of Antimicrobial Resistance. Available at: http://www.euro.who.int/en/health-topics/diseaseprevention/antimicrobial-resistance/about-amr/centralasian-and-european-surveillance-of-antimicrobialresistance-network-caesar.

World Health Organization, 2017. Fact sheet on SDGs, Antimicrobial Resistance SDG target 3.3, 1-7. Available at: $\quad$ http://www.euro.who.int/en/health-topics/healthpolicy/sustainable-developmentgoals/publications/2017/fact-sheets-on-sustainabledevelopment-goals-health-targets/fact-sheet-on-sdgsantimicrobial-resistance-sdg-target-3.3.

World Health Organization, 2018. Antibiotic resistance, 1-2. Available at: http://www.euro.who.int/en/mediacentre/sections/press-releases/2012/11/self-prescriptionof-antibiotics-boosts-superbugs-epidemic-in-theeuropean-region/antibiotic-resistance.

World Health Organization, 2018. Antimicrobial resistance, 13. Available at: https://www.who.int/en/news-room/factsheets/detail/antimicrobial-resistance.

\title{
Вопоставување на мултидисциплинарен Комитет за контрола и превенција на инфекциите како клучен фактор за рационализација на употребата на антибиотици во Клиничката болница Аџибадем Систина - Скопје
}

\author{
Драгана Бухов ${ }^{1 *}$, Зорица Наумовска ${ }^{2}$, Љубица Шутуркова ${ }^{2}$ \\ ${ }^{1}$ Клиничка болница Аиибадем Систина - Скопје, Скупи 5А, \\ 1000 Скопје, Р. С. Македонија \\ ${ }^{2}$ Институт за фармацевстка хемија, Фармацевтски факултет, \\ Универзитет „Св. Кирил и Методиј”, Мајка Тереза 47, 1000 Скопје, Р. С. Македонија
}

Клучни зборови: антибиотици, антиботска резистенција, рационална употреба на антибиотици, трошоци

Антибиотиците се индицирани за употреба при превенција и третман на бактериски инфркции. Антибиотската резистенција е глобален здравствен проблем, силно асоциран со хоспиталните инфекции. Бидејќи резистенцијата кон антибиотиците претставува глобален проблем треба да бидат развиени нови едукациски програми и стратегии за пропишување и употреба на антибиотици.

Целта на студијата е евалуација на имплементацијата на мерките од страна на Комитетот за контрола и превенција на инфекциите во Клиничкатата болница Аџибадем Систина-Скопје и проценка на фунцијата на следењето на нивото на инфекции и рационализација на пропишувањето на антибиотиците кај хоспиталните пациенти. 
Материјали кои се користеин во оваа студија се изолати од пациенти од Клиничката болница Аџибадем Систина-Скопје. Спроведни се месечни и годишни анализи од страна на фармацевт за контрола на пропишаните антибиотици согласно резултатите од антибиограм потврдени од микробиолог. Комитетот за контрола и превенција на инфекциите исто така ја следи и потрошувачката на антибиотиците меечно и на годишно ниво пресметано според Дневно Дефинирани Дози - ДДД на 1000 хоспитални денови.

Добиените резултати сугерираат дека потрошувачката на контролираните антибиотици во евалуираниот период е стабилна со тенденција на намалување. Тие се применуваат кај индицирани пациенти со исклучок на Имипенем/Циластин. Евалуацијата на претходно применуваниот начин на пропишување на овие комбинирани антибиотици сугерира дека пациентите биле суб-дозирани. Применетите контролни мерки резултирале со рационално и соодветно дозирање на пациентите и кохерентно зголемување на потрошувачката на Имипенем/Циластин. Втората применета мерка е асоцирана ос рационализација на хируршката профилакса и супституција на цефриаксон со цефазолин. Трошокот во 2016 година изнесувал 12421100 МКД (201969 ЕУР), во споредба со трошокот во 2017 од 11891000 МКД. (193 349 ЕУР).

Имплементацијата на соодветните мерки преку воспоставенниот Комитет резултирале со намалување на ирационалната употреба на антибиотици и намалување на трошоците од употребата на антибиотици во Клиничката болница Аџибадем Систина-Скопје. 
